\title{
EFEKTIFITAS BUAH MAJA SEBAGAI KONSERVAN CAGAR BUDAYA BERBAHAN LOGAM
}

\author{
Oleh : Jamili, S. E., Yuni Rahmawati S. Pd., I Aisyahis Siti \\ Balai Pelestarian Peninggalan Purbakala Serang
}

\begin{abstract}
Abstrak
Asam sitrat yang selama ini digunakan sebagai bahan konservan cagar budaya berbahan logam merupakan bahan kimia industri, yang sedikit banyak memberikan efek negatif terhadap lingkungan maupun konservator. Untuk itu diperlukan konservan alternatif yang bersifat alami yang lebih aman. Berdasarkan observasi, konservan cagar budaya berbahan logam khususnya keris yang biasa digunakan oleh masyarakat Banten adalah buah maja. Oleh karena itu, pada penelitian ini diujicobakan buah maja (Aegle marmelos (L.) Correa) sebagai bahan alternatif pengganti asam sitrat sebagai konservan cagar budaya berbahan logam. Metode yang digunakan dalam penelitian ini adalah metode eksperimen dengan langsung mengujicobakan buah maja pada alat logam berkarat. Hasilnya, buah maja efektif membersihkan karat dan kotoran lainnya pada alat logam yang semula berkarat. Artinya buah maja efektif sebagai konservan cagar budaya berbahan logam.

Kata kunci : Buah Maja, Asam Sitrat, Konservasi, Cagar Budaya Berbahan Logam.
\end{abstract}

\section{A. Latar Belakang}

Pada dasarnya semua cagar budaya berinteraksi dengan lingkungannya. Interaksi yang terjadi merupakan proses alamiah yang memungkinkan terjadinya proses penurunan fisik atau degradasi yang mengakibatkan menurunnya kualitas bahan dari benda cagar budaya, seperti kerusakan ataupun pelapukan.

Untuk meminimalisir kerusakan dan pelapukan cagar budaya diperlukan metode dan teknik konservasi yang berkualitas. Bahan kimia yang biasa digunakan sebagai bahan konservan untuk cagar budaya berbahan logam adalah asam sitrat. Kemampuan asam sitrat sebagai bahan konservan cagar budaya berbahan logam disebabkan oleh kemampuan ion sitrat yang terion saat larut dalam air dapat bereaksi dengan banyak ion logam membentuk garam sitrat. Selain itu, sitrat dapat mengikat ion-ion logam dengan pengkelatan, sehingga digunakan sebagai pengawet dan menghilangkan karat.

Demi keamanan cagar budaya dan juga kesehatan konservator, konservasi alami menggunakan bahan-bahan alami diharapkan akan menghasilkan efek yang lebih aman dibandingkan dengan konservasi menggunakan bahan kimia.

Berdasarkan observasi, konservan cagar budaya berbahan logam khususnya keris yang biasa digunakan oleh masyarakat Banten adalah buah maja. Oleh karena itu, pada penelitian ini diujicobakan buah maja (Aegle marmelos (L.) Correa) sebagai bahan alternatif pengganti asam sitrat sebagai konservan cagar budaya berbahan logam.

\section{B. Metode}

Metode yang digunakan dalam penelitian ini adalah metode eksperimen. Metode eksperimen dilakukan dengan langsung mengujicobakan buah maja pada alat logam berkarat,

\section{Tahap 1}

Variable yang diuji pada penelitian tahap 1 adalah variable masa kontak buah maja dengan objek logam serta tingkat kematangan buah maja. Untuk mengetahui pengaruh masa kontak buah maja dengan objek logam terhadap efekfitas buah maja sebagai bahan konservan, dilakukan konservasi dengan masa kontak yang bervariasi. Variasi durasi yang digunakan adalah 1, 2, 5, dan 24 jam.

Untuk mengetahui efektifitas dari segi tingkat kematangan. Buah maja yang digunakan bervariasi dari yang muda, sedang, dan tua. Konservasi dilakukan terhadap paku yang langsung ditancapan pada buah maja. Setelah masa kontak, paku dibersihkan secara mekanis dengan air kemudian dikeringkan secara alami. Dari tahap ini akan diketahui tingkat efektifitas buah maja dari segi tingkat kematangan dan efektifitas masa kontak buah maja dengan objek logam.

\section{Tahap 2}

Variable yang diuji pada tahap 2 adalah metode cara kontak buah maja dan logam. Dua cara kontak yang dibandingkan pada tahap ini adalah metode ditancapkan dan metode direndam langsung dengan durasi 1, 2, 5, dan 24 jam. Setelah masa kontak, paku dibersihkan secara mekanis dengan air kemudian dikeringkan secara alami. Dari tahap ini akan diketahui perbandingan efektifitas metode kontak buah maja dan objek logam antara metode 
ditancapkan dan direndam langsung di buah maja.

\section{Tahap 3}

Penelitian tahap 3 ini merupakan penelitian untuk memperkuat kesimpulan tahap 1 tentang pengaruh masa kontak terhadap efektifitas buah maja sebagai bahan konservan. Cara kontak yang digunakan adalah cara kontak yang paling efektif hasil penelitian tahap 2 (langsung direndam di dalam buah maja telah dihaluskan). Berbeda dengan tahap 1 yang menggunakan alat logam biasa, tahap 3 ini menggunakan benda cagar budaya berbahan logam yaitu keris yang telah berkarat. Variasi masa kontak pada tahap 3 ini memiliki interval waktu yang lebih panjang agar dapat diketahui masa kontak yang paling efektif.

Keris direndam dalam isi buah maja yang telah dihaluskan dengan durasi 24, 48, dan $72 \mathrm{jam}$. Setelah masa kontak, keris dibersihkan secara mekanis dengan air kemudian dikeringkan secara alami. Dari tahap ini akan diketahui efektifitas masa kontak antara 24, 48, atau 72 jam.

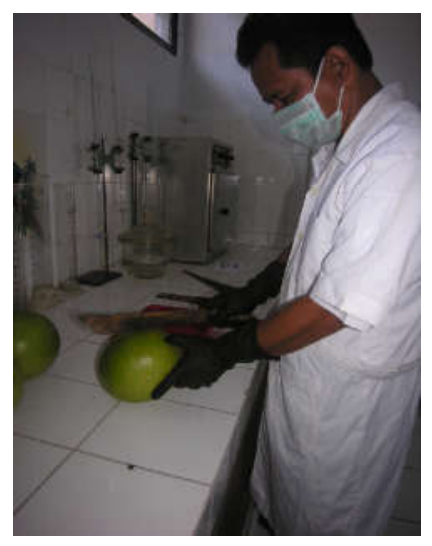

$1 a$.

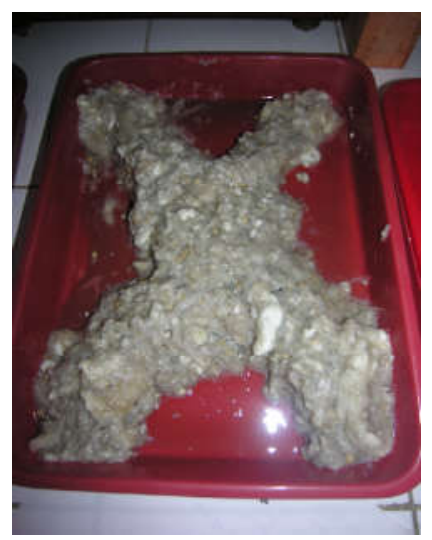

$1 c$.

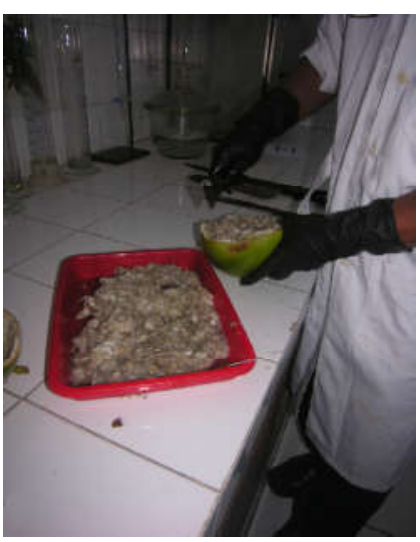

$1 b$.

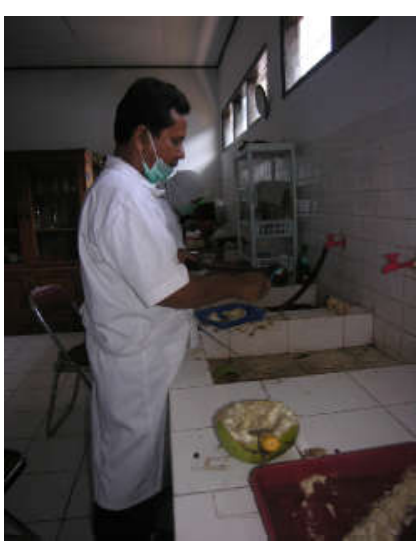

1d.
Gambar 1. Proses konservasi keris dengan menggunakan buah maja sebagai konservan

\section{Pembahasan}

Maja (Aegle marmelos (L.) Correa) / bael fruit, termasuk suku Rutaceae (jeruk-jerukan), masih keluarga dekat dengan Kawista/klawis (Limonia acidissima syn. Feronia limonia) dan Jeruk Besar (Jeruk Bali). Mengandung minyak balsam, 2-furocoumarinspsoralen, dan marmelosin $\left(\mathrm{C}_{13} \mathrm{H}_{12} \mathrm{O}_{3}\right)$, @limonen, alkaloid, scopoletin, decursinol, haplonine, anthotoxin.

Berdasar eksperimen yang dilakukan oleh tim konservasi BP3 Serang, daging buah maja dapat digunakan sebagai konservan untuk keris yang berkarat.

Tahap 1

Efektifitas buah maja sebagai bahan pengganti asam sitrat untuk konservasi cagar budaya berbahan logam sudah telihat pada tahap 1. Karat yang sebelumnya terdapat pada paku berkurang.

Pada masa kontak paku dengan buah maja dengan cara langsung ditancapkan selama durasi 1 dan 2 jam karat paku terlihat berkurang; dengan durasi 5 jam hasilnya paku terlihat lebih bersih; dengan durasi 24 jam hasilnya paku terlihat lebih bersih dari durasi 5 jam.

Dari jenis tingkat kematangan buah maja yang digunakan, buah maja tua menghasilkan hasil yang lebih efektif dibandingkan dengan buah maja muda dan sedang. Hasil ini kemungkinan berkaitan dengan tingkat keasamannya. Dari hasil pengukuran menggunakan indikator universal buah maja yang lebih muda memiliki tingkat keasaman yang lebih rendah (lebih asam).

Dari hasil ini dapat disimpulkan bahwa buah maja dapat digunakan sebagai bahan konservan untuk cagar budaya berbahan logam dengan efektifitas bertambah dengan bertambahnya masa kontak buah maja dengan objek.

\section{Tahap 2}

Jika dibandingkan dengan hasil tahap 1, karat pada tahap 2 lebih berkurang dengan tingkat efektifitas bertambah dengan bertambahnya masa kontak buah maja dengan objek.

Dari hasil ini dapat disimpulkan bahwa cara kontak dengan merendam langsung objek di dalam isi buah maja lebih efektif dibandingkan dengan menancapkan objek pada buah baja yang masih utuh. Hal ini terjadi karena saat paku direndam langsung dalam isi buah maja yang telah halus kontak paku dengan zat-zat aktif pembersih dalam buah maja lebih efektif. 


\section{Tahap 3}

Keris yang direndam dalam isi buah maja selama 3 hari (72 jam) memberikan hasil yang lebih bersih dibandingkan dengan kerisyang direndam selama 24 jam dan 48 jam. Hasil tahap 3 ini memperkuat kesimpulan tahap 1 dan tahap 2 yang menyatakan bahwa semakin lama masa kontak buah maja dengan objek logam semakin efektif fungsi buah maja sebagai bahan konservan cagar budaya berbahan logam.

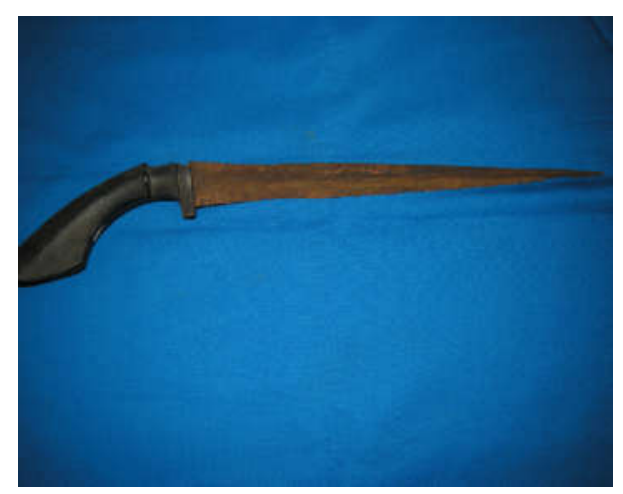

$3 a$.

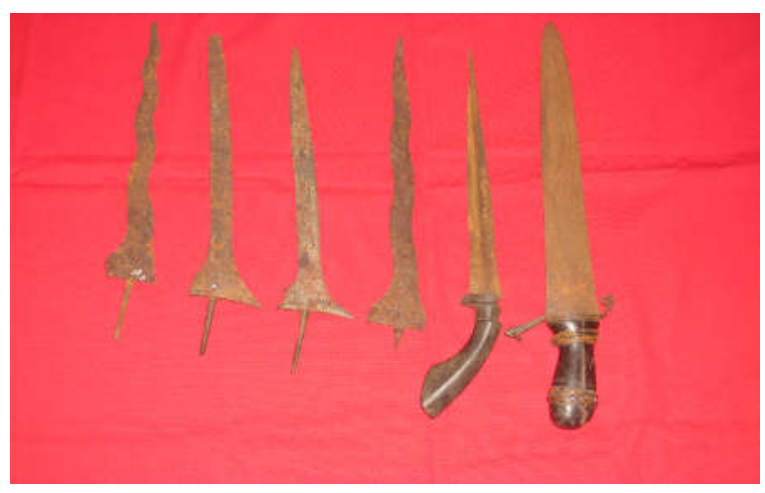

3b.

Gambar 3. Keris berkarat sebelum konservasi

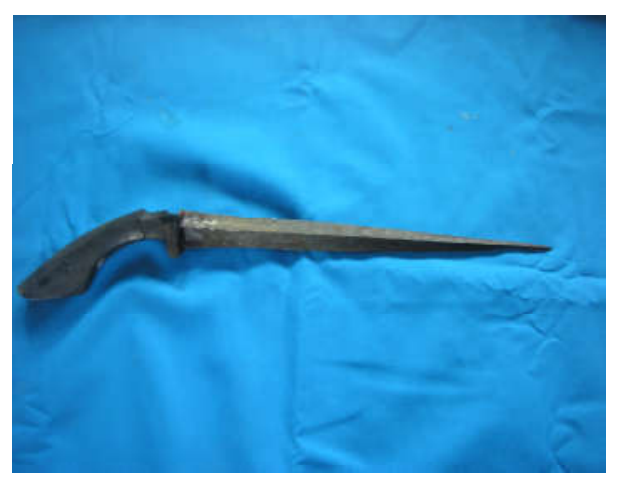

4a.

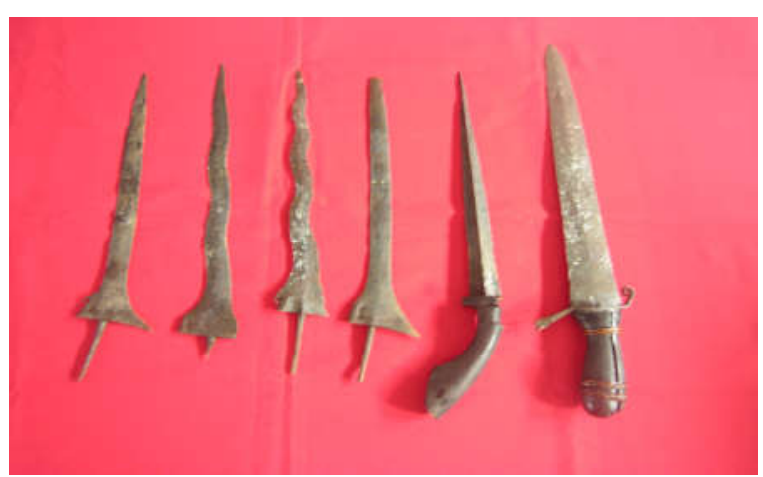

4b.

Gambar 4. Keris setelah konservasi menggunakan buah maja

\section{Penutup}

Maja (Aegle marmelos (L.) Correa) yang merupakan buah lokal Banten berdasarkan penelitian yang dilakukan tim konservasi BP3 Serang efektif digunakan sebagai konservan cagar budaya berbahan logam.

Pada penelitian ini diketahui efektifitas buah maja sebagai bahan konservan cagar budaya berbahan logam dipengaruhi oleh faktor waktu kontak dan cara kontak. Makin lama waktu kontak makin efektif buah maja bekerja sebagai bahan konservan. Sedangkan cara kontak yang paling efektif adalah dengan langsung merendam cagar budaya berbahan logam pada daging buah maja yang telah dihancurkan.

\section{Daftar Pustaka}

Hariana, Arief. 2008. Tumbuban Obat dan Khasiatnya. Penerbit Penebar Swadaya.

Sadirin, Hubertus. 2007. Metode Konservasi Benda Cagar Budaya. Jakarta: Pusat Pendidikan dan Pelatihan Departemen Kebudayaan dan Pariwisata.

http://id.wikipedia.org/. asam sitrat. (diakses pada tanggal 6 juli 2011) 